\title{
Dasar-Dasar Ontologis Pemahaman Hermeneutik Hans-Georg Gadamer
}

\author{
Agus Darmaji
}

Fakultas Ushuluddin UIN Syarif Hidayatullah Jakarta

gusdarmaji@yahoo.com

\begin{abstract}
Hans-Georg Gadamer explicitly agrees with Heidegger that 'Being' is always been understood through the language and the dimension of time. So to catch up the Being, we need to know the Being itself, and to understand it. To understand means to perceive within the time and historicity. This paper will make clear the ontological basics of Gadamer's hermeneutics containing: the relationship between historical aspect and understanding; hermeneutic discourse and sequential distance; prejudice and understanding; effective historical consciousness; understanding as application; and the structure of questions and answers.
\end{abstract}

Keywords: Understanding, Prejudice, Horizon.

Abstrak: Hans-Georg Gadamer secara eksplisit sepakat dengan Heidegger bahwa 'Being' selalu dipahami melalui bahasa dan dimensi waktu. Maka untuk menangkap Being kita perlu mengetahui serta memahami Being itu sendiri. Mengetahui berarti menghayati di dalam waktu dan sejarah. Tulisan ini akan menjelaskan dasar-dasar ontologis hermeneutika Gadamer terdiri dari: hubungan antara aspek historis dan pemahaman, wacana hermeneutika dan jarak sekuensial, prasangka dan pemahaman, kesadaran sejarah efektif, pemahaman sebagai aplikasi, dan struktur tanya dan jawab.

Katakunci: Pemahaman, Prasangka, Cakrawala. 


\section{Pendahuluan}

Dalam menjelaskan aspek baru hermeneutik, Gadamer banyak mengembangkan pemikiran Heidegger. Gadamer melihat bahwa terobosan radikal Heidegger ke masalah pemahaman ontologis hermeneutik memberi sumbangan yang sangat berharga bagi ilmu hermeneutik. Secara tegas Gadamer menyetujui pendapat Heidegger bahwa $A d a$ selalu dimengerti melalui bahasa dan dalam dimensi waktu. Maka untuk sampai pada $A d a$, kita perlu mengenal $A d a$ itu sendiri, yang berarti kita harus memahami. Memahami berarti memahami di dalam waktu dan menurut historisitasnya. Untuk itu tulisan ini akan menjelaskan tentang dasar-dasar ontologis pemahaman hermeneutik dalam perspektif Hans-Georg Gadamer yang meliputi antara lain: hubungan antara aspek kesejarahan dan pemahaman; lingkaran hermeneutik dan jarak temporal; prasangka dan usaha pemahaman; kesadaran sejarah efektif; pemahaman adalah penerapan; serta struktur pertanyaan dan jawaban.

\section{Hubungan Aspek Kesejarahan dan Pemahaman}

Sebelum dijelaskan bagaimana gerak historis dalam pemahaman terjadi, pertama-tama perlu dipahami bagaimana Gadamer mengartikan 'sejarah.' Menurut Gadamer, pengetahuan kita, bahkan seluruh hidup kita, secara intrinsik dipengaruhi oleh kesejarahan yang kita hidupi di masa lampau kita: entah pengaruhnya pada ide-ide kita, lembaga-lembaga, realitas politik, maupun sosio-ekonomi. Oleh karena itu, tidak perlu diragukan bahwa cakrawala besar masa lampau kita sangat berpengaruh pada diri kita dalam menentukan apa yang kita inginkan, kita harapkan, atau kita takuti di masa depan. ${ }^{1}$

Menerima hubungan erat antara masa lampau dan masa kini dapat memunculkan penolakan kritis bahwa tidak semua sejarah atau pengetahuan sejarah berhubungan dengan diri kita. Misalnya, bagaimana hubungan diri kita dengan studi mengenai suku Bushman? Kenyataan ini disetujui Gadamer, namun demikian, diri kita tetap secara intrinsik memuat hubungan antara sejarah dan situasi kekinian kita, termasuk di dalamnya bagaimana cara kita memahami. Dengan demikian, hubungan antara kesejarahan dan pemahaman itu pada dasarnya bersifat intrinsik. 
Gadamer juga melihat hubungan reflektif dari sejarah dalam kaitannya dengan pemahaman. Menurutnya, kita senantiasa berusaha untuk memahami, mengritisi, mengasimilasi sesuatu; tapi di sisi lain juga membiarkan pengalaman kita di masa lampau memberikan pengertian tentang diri kita, menempatkan diri kita dalam suatu perspektif tertentu. Jadi, hubungan kedua ini menunjuk pada hubungan reflektif, yang berarti bahwa hubungan antara kesejarahan dan pemahaman dapat bersifat positif dan dapat juga negatif. Hubungan antara aspek kesejarahan dan pemahaman secara intrinsik menuntut suatu praksis tertentu. Gadamer melihat bahwa praksis bukan sesuatu yang eksternal, karena pemahaman sendiri dinilai sebagai suatu tindakan. Sehingga pemahaman itu sendiri pada dasarnya merupakan praksis. Maka di samping pemahaman itu merupakan tindak reflektif, sekaligus juga historis. Memahami berarti menciptakan makna baru atau menafsirkan sedemikian rupa sehingga tindakan semacam ini akhirnya menjadi bagian dari sejarah atau tradisi yang akan diwariskan untuk generasi mendatang.

Hubungan selanjutnya adalah bahwa karena pemahaman itu bersifat historis maka juga bercorak temporal dan mengandaikan suatu proses tertentu. Hal ini dapat dirujuk pada apa yang pernah diilustrasikan Herakleitos bahwa 'kita' tidak pernah identik secara total, karena kita selalu berkembang, termasuk proses pemahaman kita akan diri sendiri. 'Sungai yang sama' tidak pernah ada karena yang dulu ada dan sekarang ada selalu berbeda dan terus berubah. ${ }^{2}$

Heidegger dalam uraian mengenai pra-struktur pemahaman (prestructure of understanding) dan aspek kesejarahan intrinsik (intrinsic historicality) eksistensi manusia, menjelaskan bahwa interpretasi atau penafsiran tidak pernah tercapai jika tidak ada prasangka sebelumnya. ${ }^{3}$ Menurut Heidegger, kita memahami sesuatu tidak dari suatu kesadaran kosong, melainkan justru karena di dalam diri kita sudah tersimpan lebih dahulu intensi-intensi tertentu berkenaan dengan apa yang ingin kita pahami. Dalam diri kita sudah ada prasangka tertentu. Oleh karena itu, tidak mungkin ada pemahaman kekinian yang dimengerti tanpa mengandaikan masa lampau atau sebaliknya. Dengan kata lain, aktus pemahaman terikat pada ruang dan waktu keberadaan penafsir sendiri. Tidak heran jika Gadamer 
menganggap tradisi pemaknaan sebagai titik pijak keberadaan manusia. Masa lampau bukanlah sekedar tumpukan fakta yang dapat dipandang sebagai obyek kesadaran, melainkan lebih sebagai suatu aliran dinamis di mana kita bergerak dan berpartisipasi di dalam setiap usaha memahami. ${ }^{4}$

\section{Lingkaran Hermeneutik dan Jarak Temporal}

Satu model yang menunjuk kesejarahan pemahaman adalah model lingkaran hermeneutik, khususnya sebagaimana dikembangkan oleh Heidegger. Secara tradisional, lingkaran hermeneutik mengandung makna bahwa teks harus ditafsirkan secara sirkular: bagian-bagian harus dilihat dalam keseluruhan dan sebaliknya keseluruhan harus dipandang juga menurut bagian-bagiannya. Ini berarti bahwa proses pemahaman memerhitungkan kaitan erat antara keseluruhan dengan masing-masing bagiannya.

Misalnya kalau kita ingin memahami suatu kata tertentu dalam suatu kalimat, maka kita harus meletakkan kata tersebut dalam totalitas kalimat dan juga totalitas teks yang bersangkutan. Bahkan sering kita harus meluaskan konteksnya, katakan misalnya teks tersebut harus dilihat dalam kaitannya dengan aliran sastra yang berlaku saat itu. ${ }^{5}$ Pemikiran tersebut masih diteruskan lebih lanjut oleh Dilthey dengan memasukkan unsur dunia sejarah yang menurut pendapatnya harus selalu menjadi prinsip seluruh penafsiran tekstual. Teori hermeneutik abad sembilan belas sering berbicara mengenai struktur pemahaman melingkar tersebut namun selalu dalam kerangka hubungan formal antara keseluruhan dan masing-masing bagian.

Menurut terori di atas, gerak pemahaman melingkar atau sirkulasi maju mundur sepanjang proses pemahaman akan menghilang saat teks tersebut dimengerti. Berlawanan dengan hal itu, Heidegger memberikan gambaran mengenai lingkaran hermeneutik yang menjadi titik balik yang sangat menentukan dalam diskusi hermeneutik. Heidegger menggambarkan proses pemahaman melingkar itu sedemikian rupa sehingga pemahaman teks secara permanen ditentukan oleh adanya pra-pemahaman terlebih dahulu. Lagi pula, lingkaran antara keseluruhan dan masing-masing bagian tidaklah selesai dengan muncul pengertian. Dengan pernyataan ini, 
Heidegger ingin menyatakan bahwa pemahaman yang tuntas itu tidak akan pernah terjadi.

Hal itu akan lebih jelas jika dilihat pada uraian Gadamer atas penyingkapan konsep pra-struktur pemahaman Heidegger yang terdiri dari tiga unsur yaitu Vorhabe, Vorsicht, dan Vorgriff. ${ }^{6}$ Menurut Gadamer, Heidegger mendiskusikan lingkaran hermeneutik pertama-tama bukan sebagai usaha pemahaman praktis, melainkan dimaksudkan untuk memberikan deskripsi cara pencapaian pemahaman melalui interpretasi. Heidegger mengatakan bahwa jika seseorang ingin memahami sesuatu ia membawa latar belakang tradisi yang telah ia miliki sebelumnya. Unsur pertama dalam lingkaran hermeneutik itu disebut dengan Vorhabe (fore-have.) Selanjutnya dalam membuat penafsiran, orang itu selalu dibimbing oleh cara pandang tertentu. Maka dari itu dalam setiap tindak pemahaman ia selalu didasari oleh apa yang telah dilihat sebelumnya. Itulah unsur yang dinamakan Vorsicht (fore-sight.) Unsur ketiga yang menjadi syarat pemahaman adalah konsep-konsep yang memberi kerangka awal yang diistilahkan dengan Vorgriff(fore-conception.)

Ketiga unsur tersebut menjadi syarat pemahaman dalam lingkaran hermeneutik yang bertitik tolak dari konsep ontologis Heidegger yang lebih mendasar yaitu 'Berada di' (Being there) dari Dasein yang terikat pada temporalitasnya. Gadamer menandaskan apa yang telah dikatakan Heidegger bahwa lingkaran hermeneutik bukanlah suatu lingkaran setan yang tidak berujung pangkal dan sia-sia belaka. Namun justru dalam gerak maju melingkar itu terkandung kapasitas primodial pemahaman manusia yang positif karena pra-pengertian demi pra-pengertian akan diperbaiki terus menerus.

Dengan demikian, proses pemahaman melalui lingkaran hermeneutik memerhitungkan kaitan antara keseluruhan dan masing-masing bagian dan sebaliknya, sebagaimana telah diterangkan sebelumnya mengandaikan adanya keterbukaan untuk menerima pemahaman-pemahaman baru. Gadamer memerjelas proses itu dengan mengatakan bahwa seseorang yang ingin berusaha untuk mengerti sebuah teks selalu dibimbing oleh suatu tindak proyeksi. Artinya, saat ia berhadapan dengan sebuah teks, ia akan merancang makna-makna bagi keseluruhan teks tersebut begitu ia mulai menangkap beberapa makna ketika mulai mencermati teks. Dengan 
beberapa makna yang menjadi proyeksi awal itu, ia akan melanjutkan proses pemahaman. Pemahaman demi pemahaman akan diperbarui secara terus menerus dan kadang harus menyingkirkan pemahaman yang tidak benar.

Penggambaran proses di atas memang kasar, namun dapat menegaskan apa yang dimaksud oleh Heidegger. Proses terus menerus dari pra-pemahaman satu ke berikutnya itu adalah gerak dari proses pemahaman dan interpretasi. Selanjutnya ditandaskan oleh Heidegger bahwa gerak lingkaran pemahaman bukanlah suatu lingkaran metodologis melainkan sebuah elemen mendasar atau ontologis dalam setiap pemahaman. ${ }^{7}$

Sepertinya gambaran di atas menyiratkan tidak adanya 'obyektifitas' dalam penafsiran. Ini membawa konsekuensi juga bahwa tugas membaca teks untuk mengerti 'apa yang dimaksud' akhirnya selalu akan kandas pada fakta bahwa di dalam membaca teks selalu hanya ada perkiraan-perkiraan. Maka sekalipun penafsiran-penafsiran diusahakan untuk tidak memerhatikan apa yang dimaksud oleh teks tersebut, pra konsepsi-pra konsepsi akan tetap ada. Maka satu-satunya 'obyektifitas' hanyalah konfirmasi atas makna-makna yang sudah ada sebelumnya. Menghadapi persoalan ini, Gadamer kemudian menunjukkan kritiknya terhadap gagasan lingkaran hermeneutik Schleiermacher yang menyatakan bahwa suatu pemahaman hanya dapat terjadi dalam keseluruhan aspek obyektif dan subyektif. Kalau Schleiermacher membedakan lingkaran hermeneutik atas bagian dan keseluruhan menurut aspek obyektif dan Subyektifnya, ini berarti ia mengandaikan bahwa pemahaman harus masuk ke dalam realitas intensi pengarang atau masuk ke dalam batin hidup pengarang. Seperti dijelaskan oleh Gadamer:

When we try to understand a text, we do not try to recapture the author's attitude of mind but, if this is the terminology we are to use, we try to recapture the perspective within which he has formed his views. But this means simply that we try to accept the objective validity of what he is saying.

Dengan demikian rupanya Gadamer ingin mengurangi unsur personal yang berlebihan di dalam pemahaman: pemahaman lebih terarah pada persoalan yang dibicarakan. Maka memuatkan perhatian 
terlalu berlebihan pada apa yang dimaksud oleh pengarang bukanlah cara efektif untuk menafsirkan. Cara yang baik adalah memfokuskan diri pada 'fakta-fakta' yang sudah tersedia dan siap diinterpretasikan. Itu sebabnya jika dikatakan bahwa proses gerak melingkar pemahaman bukan suatu tindakan Subyektif adalah karena makna-makna awal yang mengarahkan proses pemahaman kita merupakan gerak maju dari hal-hal umum yang mengingatkan kita pada tradisi tertentu. Namun di sisi lain Gadamer juga menolak aspek obyektif yang berlebihan. Ia menyangkalnya dengan cara yang sama seperti ketika Gadamer mengritik obyektifitas dalam sains. Setiap proses yang berusaha memahami masa lampau dengan acuan situasi kekinian kita, dengan sendirinya menyangkal semua analisis obyektif final. Artinya, ide Schleiermacher mengenai lingkaran obyektif terkait erat dengan pemahaman total. Menurut Heidegger, juga disetujui Gadamer, pemahaman total dan tuntas itu tidak pernah terjadi. Bahkan penafsir pun tidak semata-mata hanya tergantung pada obyek pemahamannya saja. Dengan demikian proses ini memerhitungkan juga aspek kesejarahannya. Jadi yang terjadi bukan hanya sekedar reproduksi melainkan juga produksi makna. Sehubungan dengan hal itu Gadamer menulis:

Every age has to understand transmitted text in its own way, for the text is part of the whole of the tradition in which the age takes an objective interest and in which it seeks to understand itself. The real meaning of a text, as it speaks to the interpreter, does not depend on the contingencies of the author and whom he originally wrote for.

Konsekuensi logis dari pernyataan di atas adalah bahwa jarak temporal (temporal distance) yang membentang antara penafsir dan teks atau peristiwa masa lampau, bukanlah jurang yang menghambat penafsiran dan harus dihindari karena dianggap negatif. Sesungguhnya rentang waktu itu menjadi dasar pendukung proses di mana kekinian berakar. Tetapi harus tetap dingat bahwa penemuan makna-makna atas suatu teks adalah proses yang tidak pernah selesai. Dalam proses tersebut sumber-sumber yang sesat dan mengaburkan makna secara terus menerus dibersihkan. Seringkali tersingkap juga makna-makna baru yang tidak diharapkan sebelumnya. 
Dalam banyak hal, diskusi mengenai lingkaran hermeneutik melibatkan juga ide tentang jarak temporal (temporal distance.) Ini berarti bahwa dalam upaya memahami sesuatu mau tidak mau melibatkan juga ide tentang waktu. Waktu memainkan peranan penting untuk memahami apa yang kita terima dari masa lampau.

Pada abad ke-19, waktu dinilai dalam masa Romantik sebagai sesuatu yang menghambat pemahaman, yang mencegah kedekatan dengan apa yang akan dimengerti. Waktu menjadi aral melintang yang harus dijembatani atau sesuatu yang harus sesegera mungkin diatasi. Gadamer menentang ide ini dan dengan meminjam konsep Heidegger sebagai titik acuan pemikirannya.

For the hermeneutic importance of temporal distance could be understood only as result of the ontological direction that Heidegger gave to understanding as an 'existential' and his temporal interpretation of the mode of being of there-being. ${ }^{10}$

Di sini Heidegger mau mengatakan bahwa waktu merupakan basis yang mendukung proses berakar kekinian kita. Sekaligus juga sebagai tempat berlangsung pemahaman dan interpretasi serta model ontologisme yang paling fundamental. Singkatnya, waktu menjadi faktor yang mutlak bagi pengetahuan dan juga produktif.

Waktu dapat dijembatani oleh kontinuitas adat istiadat dan tradisi. Ibarat waktu adalah 'ether' di mana proses penafsiran berlangsung. Maka waktu, menurut Gadamer, juga dapat dikatakan sebagai 'filter' penyaring untuk menghapus interpretasi-interpretasi yang tidak sesuai. Kita sadar akan ide ini khususnya dalam memelajari ilmu sejarah, karena peristiwa-peristiwa sejarah hanya dipelajari ketika ada jarak temporal dengan kita.

Karena jarak temporal juga berfungsi sebagai proses penyaring, maka proses waktu dapat berperan sebagai pelaku yang aktif. Gadamer menyebut waktu sebagai yang memberi kita kriteria meyakinkan, yang membiarkan makna sejati obyek muncul secara utuh atau menyebabkan prasangka-prasangsa yang menghasilkan pemahaman asali muncul secara jelas sebagai yang demikian. Tidak heran jika Gadamer menyebut nilai utama dari jarak temporal adalah 'keterbukaan.' Keterbukaan dan anti-dogmatisme merupakan nilai terpenting bagi Gadamer: 'falsafat pada dasarnya 
merupakan pencerahan, dan pencerahan itu sendiri persisnya menentang dogmatisme dari dirinya sendiri.' Pencerahan berarti juga keterbukaan, tetap memelihara proses penafsiran dan pemahaman. Jika keterbukaan itu sungguh-sungguh merupakan nilai terpenting, maka jarak temporal itu sendiri menjadi sesuatu yang vital dan positif

\section{Keberatan Gadamer atas Konsep Prasangka}

Bagi penganut Hermeneutik Romantis, prasangka dan tradisi dipandang sebagai penghalang untuk memahami dan menafsirkan, bahkan kedua mereka dipertentangkan dengan kebenaran yang mau mereka capai. Dengan tegas Schleiermacher dan Dilthey menyatakan bahwa situasi kekinian (presentness) penafsir hanya memunyai arti negatif dalam usaha hermeneutis. Situasi ini dipandang sebagai sumber prasangka-prasangka dan distorsi-distorsi yang memblokir pemahaman yang benar dan sah. Oleh karena itu prasangka harus dilampaui oleh penafsir.

Dengan demikian menurut teori itu pemahaman sejarah adalah tindak Subyektif untuk menanggalkan semua bentuk prasangka dan untuk mereproduksi pengalaman pengarang atau peristiwa masa lampau. Cara berpikir semacam ini dapat dikembalikan pada ide Cartesian dan cara berpikir jaman Pencerahan yang mengidealkan kemampuan Subyek rasional untuk melepaskan diri dari ikatanikatan sejarah dan berbagai macam prasangka yang terkandung dalam ikatan-ikatan sejarah itu. Mereka berusaha untuk mengejar pemahaman obyektif karena iklim mengagung-agungkan kekuatan akal budi. Oleh Gadamer, pemikiran demikian dikritik karena berarti penafsir menolak ikatan obyektifnya dengan aspek kesejarahannya pada masa kini. ${ }^{11}$

Keterasingan metodologis yang dialami penafsir karena mengingkari ikatannya pada aspek kesejarahannya menjadi kritik Gadamer terhadap Hermeneutik Romantik dan kecenderungan diberlakukan cara kerja ilmu-ilmu alam dan ilmu-ilmu kemanusiaan. Terhadap teori Hermeneutik Romantik itu Gadamer mengajukan pertanyaan mendasar: bagaimana mungkin seorang yang ingin memahami suatu teks atau peristiwa masa lampau dapat meninggalkan ikatan historisnya dengan masa sekarang begitu saja 
hanya dengan mengambil sikap tertentu? Bagaimana mungkin melakukan transposisi diri (self transpotition) atau proyeksi negatif untuk menjadi 'teman sejaman' pengarang atau pelaku sejarah di masa lampau seperti disarankan penganut Hermeneutik Romantik? Usaha transposisi diri semacam itu berarti menolak dan mengingkari jarak temporal (temporal distance) yang memisahkan dirinya dengan obyek yang bersangkutan. Jalan pemahaman semacam itu problematis karena menuntut kita untuk melampaui ikatan dengan masa kini dan aspek historisnya. Hal itu hanya dapat dimengerti jika asumsi bahwa historisitas seseorang adalah sekedar faktor aksidental atau kebetulan belaka. Namun karena itu adalah faktor ontologis, maka situasi kekinian seorang penafsir secara konstitutif sudah termasuk dalam setiap proses pemahaman itu sendiri. ${ }^{12}$

Bertitik tolak dari jalan pemikiran tersebut, Gadamer menyatakan bahwa keterikatan seseorang pada cakrawala historisitas kekiniannya dan juga jarak temporal yang terbentang memisahkan dirinya dengan obyek yang mau dimengerti sebenarnya justru menjadi dasar produktif semua usaha pemahaman daripada menjadi faktor negatif yang menghalangi pemahaman sebagaimana dilihat penganut Hermeneutik Romantik.

\section{Rehabilitasi Konsep Prasangka, Otoritas, dan Tradisi}

Dalam pembicaraan mengenai struktur lingkaran hermeneutik, Gadamer berbicara tentang konsep-konsep yang ada sebelumnya sebagai yang hadir ketika kita memahami sesuatu. Untuk memertahankan bahwa pandangan ini penting dalam pemahaman, ia kemudian berusaha merehabilitasi tiga macam konsep awal tersebut: prasangka, otoritas, dan tradisi. Gadamer ingin memberi makna positif atas ketiga hal itu, yang selama ini lebih terkesan negatif.

Menurut Gadamer, istilah prasangka telah menerima konotasi negatif pada masa Pencerahan. Ia berpendapat bahwa "prasangka mendasar yang ada pada masa Pencerahan ialah prasangka melawan prasangka sendiri, yang konsekuensinya mencabut tradisi dari akar kekuatannya."13 Bahkan Gadamer mancatat bahwa kemunculan historisisme pada abad ke-19 sama sekali tidak memersoalkan hal ini, melainkan hanya berbicara mengenai historisisme yang secara 
implisit menerapkan gagasan standar a-hitoris. Menurut mereka, dengan standar ini, semua kebenaran dianggap relatif secara historis, dan rasio itu superior serta mampu mengatasi setiap prasangka. Pengertian negatif di atas sebenarnya merupakan suatu penyempitan makna yang muncul dari proses pewarisan pemakaian bahasa. Adalah lebih baik dan adil jika pengertian prasangka dikembalikan ke maknanya yang asali dan netral. Artinya, dalam proses pertimbangan dapat muncul prasangka yang positif dan juga negatif. Bahkan untuk menunjukkan ada sesuatu ini ia sempat menguraikan 'kapasitas atau kemampuan positif dari prasangka' dengan memerlihatkan efek atau pengaruh jarak temporal yang terjadi.

It is only this temporal distance that can solve the really critical question of hermeneutics, namely of distinguishing the true prejudices, by which we understand, from the false ones by which we misunderstand. ${ }^{14}$

Pandangan mengenai prasangka ini membawa Gadamer masuk ke dalam diskusi mengenai konsep yang menghubungkan rasiootoritas dan tradisi. Pada masa Pencerahan, terdapat pemisahan yang tegas antara rasio di satu sisi dan prasangka dengan otoritas di sisi lain. Menurut mereka, 'yang menjadi sumber utama dari segala otoritas bukanlah tradisi melainkan rasio.' Menurut Gadamer, pemisahan ini keliru dan merupakan prasangka melawan prasangka. Seolah-olah rasio saja yang memunyai fungsi otoritatif, sedangkan tradisi dan otoritas pribadi atau ide-ide tidak memiliki. Sesungguhnya, otoritas merupakan sesuatu yang kita peroleh dan yang harus dikenali. Untuk dapat memerintah dan membuat orang taat, seseorang harus memunyai otoritas dan dikenali otoritasnya. Maka pengenalan akan otoritas merupakan suatu yang muncul dari kebebasan dan rasio. Dengan kata lain, untuk mengenal otoritas, otoritas itu sendiri harus dilihat secara rasional dan bukan sewenang-wenang. ${ }^{15}$

Istilah terakhir yang diuraikan Gadamer adalah tradisi. Menurutnya, tradisi merupakan suatu bentuk otoritas. Tradisi dan adat istiadat memunyai otoritas: apa yang diwarikan kepada kita dari masa lampau memiliki daya cengkeramnya pada kita dan senatiasa dipelihara dan dipertahankan. Misalnya saja di dalam dunia pendidikan, otoritas diberikan kepada guru, sekalipun ia juga tetap 
harus bergantung pada nilai-nilai tradisi yang diwariskan dan ada dalam dunia pendidikan. Sama halnya para siswa, pada titik tertentu mereka juga harus masuk ke dalam suatu dialog kritis, walaupun pada prosesnya apa yang mereka terima dari tradisi harus tetap dipertahankan untuk memerkaya kritik dan apa yang mereka miliki atasnya. Dengan kata lain, tradisi dipahami sebagai upaya penemuan identitas diri kita sendiri.

Diskusi mengenai prasangka, otoritas, dan tradisi ini juga memunculkan tegangan mendalam terhadap pandangan Gadamer mengenai kesejarahan pemahaman. Di satu sisi, penafsir harus menerima prasangka, otoritas, dan tradisi sebagai yang diterima begitu saja dalam dirinya (given), tapi di sisi lain, ia juga harus menggunakan rasionya untuk dapat menerima dan mengenali sesuatu. Maka tetap ada kekurangjelasan bagaimana Gadamer melihat prasangka, otoritas, dan tradisi sebagai faktor yang selalu hadir ketika kita mengetahui. Gadamer ingin mengungkapkan bahwa rasio harus mengenali ketiganya agar ketiganya itu bisa legitim, tapi ia juga mengatakan bahwa ketiganya itu merupakan faktor konstitutif bagi pengetahuan bagaimanapun kita berpikir.

\section{Prasangka sebagai Syarat Pemahaman}

Gadamer memberikan alasan mengapa situasi penafsir bersifat positif dalam melakukan penafsiran. Ia memberikan peringatan bagaimana itu harus dimengerti dengan benar.

A person trying to understand a text is prepared for it to tell him something. That is why a hermeneutically trained mind must be, from the start, sensitive to the text's quality of newness. But this kind of sensitivity involves neither 'neutrality' in the matter of the object nor the extinction of one's self, but the conscious assimilation of one's own fore-meaning and prejudice. The important thing is to be aware one's own bias, so that the text may present itself in all its newness and thus be able to assert its own truth against one's own fore-meanings.

Gadamer menyatakan alasan mengapa prasangkayang mendahului proses pemahaman bukanlah suatu kesewenang-wenangan:

.....understanding achieves its full potentiality only when the fore-meaning that it uses are not arbitrary. Thus it is quite right 
for the interpreter not to approach the text directly, relying solely on the fore-meaning at once available to him, but rather to examine explicitly the legitimacy, i.e. the origin and validity, of the fore-meaning present within him. ${ }^{17}$

Namun agar konsep mengenai prasangka tidak disalah-mengerti, sejak awal Gadamer juga memeringatkan bahwa dalam usaha memahami suatu teks kita harus tetap terbuka terhadap aspek-aspek baru yang mungkin muncul ketika proses pemahaman dilangsungkan. Dengan demikian, sebenarnya suatu interpretasi definitif secara prinsipial tidak mungkin diberikan. Itulah yang dimaksud kalau dikatakan bahwa masing-masing generasi berhak memahami dan menafsirkan. Hal yang penting untuk diperhatikan adalah mewaspadai bias-bias yang dapat terjadi dalam proses itu sehingga teks yang bersangkutan menghadirkan dirinya sendiri sampai ia sendiri mampu mengungkapkan kebenarannya saat dihadapkan pada rangkaian pramakna yang ada dalam diri penafsir sejak awal. Suatu interpretasi secara terus menerus dapat menyingkirkan prasangka-prasangka yang tidak cocok dan terbuka dengan prasangka yang benar. Tugas hermeneutikalah untuk memilah-milah prasangka-prasangka yang legitim dari prasangka-prasangka yang tidak legitim.

\section{Cakrawala Historis Pemahaman sebagai Makhluk Historis}

Bagi Gadamer, pemahaman dapat dilakukan justru karena obyek yang hendak dipahami dan Subyek penafsir bukanlah dua hal yang saling terasing. Dengan kata lain, hanya jurang waktu yang memisahkan, kedua mereka bukanlah penghalang proses pemahaman. Hal itu dikarenakan kedua mereka berada dalam hubungan satu dengan yang lain dalam ikatan tradisi. Baik Subyek penafsir maupun obyek pemahaman adalah bagian dari suatu tradisi budaya dan sejarah yang terbentuk dalam kontinuitas yang oleh Gadamer disebut dengan sejarah-efektif (effective-history, Wirkungsgeschichte) yang akan membentuk prasangka dan menjadi syarat pemahaman.

Kesadaran sejarah-efektif pertama adalah kesadaran akan situasi hermeneutis yaitu bahwa kita ada dalam arus tradisi makna tertentu yang ingin kita pahami. Oleh karena itu, tidak mengherankan kalau tindak pemahaman selalu terkait dengan situasi tertentu dengan 
berbagai batas-batasnya. Gadamer mengistilahkan dengan 'horison' atau cakrawala pandang yang dapat diartikan sebagai jangkauan pandangan yang mencakup apa saja yang dapat dilihat dari suatu titik pandang tertentu. ${ }^{18}$

Gadamer menjelaskan maksud istilah tersebut lebih lanjut dengan mengatakan bahwa seseorang yang tidak memunyai cakrawala pandang adalah orang yang tidak melihat cukup jauh dan luas sehingga penilaian-penilaiannya dilandasi oleh faktor-faktor yang sangat sempit. Sebaliknya, orang yang memunyai horison adalah orang yang tidak terkungkung pada apa yang terdapat dalam cakupan pandangan sekilasnya saja namun ia mampu melihat di balik apa yang segera tampak di hadapannya. Orang yang memunyai horison luas juga mampu melihat kaitan-kaitan penting yang menghubungkan antar bagian-bagian dengan keseluruhan dan begitu pula sebaliknya. Demikian pula yang terjadi dalam problematika hermeneutik. Pencapaian horison yang benar ditempuh dengan cara menyelidiki dan mencermati pertanyaan-pertanyaan yang ditimbulkan berkat perjumpaan-perjumpaan penafsir dengan tradisi. Pernyataan bahwa kita memahami suatu teks dengan cakrawala kita tidak berarti itu pemahaman yang benar satu-satunya. Cakrawala pemahaman bagaikan sebuah sudut pandang khusus atau optik yang eksklusif. ${ }^{19}$

Menurut Gadamer, untuk memahami masa lampau dituntut ada cakrawala horison tertentu. Tetapi ini bukanlah perkara bahwa kita kemudian menempatkan diri pada situasi historis tersebut begitu saja. Menurut Gadamer, transposisi diri atau menjadi teman sejaman dengan pengarang atau pelaku sejarah di masa lampau seperti yang diusulkan oleh Schleiermacher dan Dilthey cukup problematis. Maka jika Gadamer mengatakan perlunya cakrawala historis maksudnya adalah bahwa kita harus sudah memunyai suatu cakrawala untuk menempatkan diri kita sendiri dalam situasi historis. Jadi lebih mendekati konsep fore-have yang disinyalir oleh Heidegger. Kemudian pertanyaan kita adalah apakah artinya menempatkan diri dalam situasi historis di sini? Apakah kemudian aspek historisitas penafsir harus dikalahkan agar dapat sepenuhnya melakukan pemahaman?

Jawaban atas problem ini sebenarnya sudah dibangun ketika Gadamer menganalisis dunia kesenian secara hermeneutik. Pada bagian 
itu ia menyatakan bahwa dalam memahami karya seni, dunia historis kita menjadi semacam perangkat dan melebur dalam menyikapi dan merasai titik estetis dari suatu karya seni. Artinya, di sana terjadi suatu peleburan antara cakrawala kita dengan cakrawala arus makna tradisi tertentu. Manusia yang memiliki kesadaran sejarah selalu terikat dengan kekiniannya sedemikian rupa sehingga ia mampu melihat dirinya sendiri sebagaimana ia melihat yang lain secara historis pula. Dalam pertemuan itu, cakrawala masa sekarang secara terus menerus dibentuk dalam pertemuannya dengan cakrawala-cakrawala masa lampaunya. Bagian yang terpenting adalah pertemuan dengan masa lampau dari mana cakrawala masa sekarang berasal. Oleh karena itu, cakrawala masa sekarang tidak dapat dipisahkan dari cakrawala masa lampau. Maka, setiap proses pemahaman adalah peleburan dari dua macam horison atau cakrawala (fusion of horizon, welding of horizons).

\section{Konsep Peleburan Cakrawala}

Gadamer menyatakan bahwa dalam kenyataannya cakrawala yang dimiliki seseorang pada masa sekarang terbentuk sebagai akumulasi berbagai cakrawala di masa lampau dalam gerak melingkar terus menerus. Oleh karena itu, dapat dikatakan bahwa cakrawala yang dimiliki seseorang sekarang tidak dapat terbentuk tanpa ada cakrawala-cakrawala di masa lampau. Setiap perjumpaan dengan tradisi pemaknaan tertentu terjadilah peleburan cakrawala. Hal itu terjadi dalam kesadaran historis yang mau tidak mau menyertakan dua kutub jagat makna yaitu: teks yang dipahami dan makna dari seorang penafsir yang akan membentuk cakrawalanya.

Tugas hermeneutik bukan untuk menutupi ada ketegangan antara dua kutub makna itu dengan melakukan asimilasi naif, melainkan dengan kesadaran. Kedua cakrawala itu tidak berada dalam posisi vis$\grave{a}$-vis. Kedua mereka hanya dapat dimengerti kalau dilihat hubungan yang ada di antara mereka. Mencari makna dari masing-masing per se adalah tindakan sia-sia, yang harus dilakukan adalah dengan memerlawankan satu sama lain. ${ }^{20}$

Dengan demikian dalam kesadaran sejarah orang dituntut untuk bersikap waspada atas keunikan cakrawalanya sendiri yang pada gilirannya mampu membedakan dirinya dari cakrawala tradisi, 
meskipun disadari bahwa tidak akan pernah ada suatu rekonstruksi historis secara menyeluruh. Proyeksi dari cakrawala historis itu adalah sekedar suatu tahap dalam proses pemahaman yang tidak menjadi suatu alienasi kesadaran masa lampau seorang penafsir. Dalam proses pemahaman itu terjadi peleburan sejarah yang dapat digambarkan dengan suatu tindak kesadaran. Itulah yang menjadi bagian dari tugas kesadaran sejarah-efektif (effective-historical consciousness).

Kesadaran sejarah-efektif itu dikaburkan oleh Positifisme yang juga diikuti oleh kelompok Hermeneutik Romantik. Konsep ini menjadi penegasan Gadamer untuk membedakan antara ilmu-ilmu kemanusiaan dengan ilmu-ilmu kealaman yang menjadi sumbangan Gadamer yang amat penting bagi perkembangan ilmu-ilmu kemanusiaan. Dalam ilmu-ilmu kemanusiaan, obyek penyelidikan tidak termuat dalam obyek itu sendiri tetapi dikonstitusikan oleh motivasi dari penyelidikannya. Dengan asumsi itu, Gadamer menolak diterapkannya cara kerja ilmu-ilmu kealaman bagi ilmu-ilmu kemanusiaan. Untuk memahami ilmu-ilmu kemanusiaan diperlukan suatu basis kesadaran sejarah yang berkaitan erat dengan pengalaman manusiawi yang dilengkapi dengan unsur-unsur kemanusiaannya. Metode kerja ilmu-ilmu kealaman tidak memerhitungkan hal itu karena pertama-tama memang mau menekankan bahwa pengalaman adalah sesuatu yang dapat diulang dan diulang lagi begitu saja (repeatability of experience) seperti proses percobaan balon lampu yang dialiri listrik dengan kondisi-kondisi tertentu akan selalu menyala. Penekanan pada repeatability of experience ini mengesampingkan aspek historis dalam gejala kemanusiaan dan terlalu menyederhanakan gejala-gejala sosial dalam deretan angka dan statistik. Maka Gadamer menilai kepercayaan naif pada metode ilmu-ilmu kealaman untuk dijadikan metode ilmu-ilmu kemanusiaan akan melahirkan suatu ilmu pengetahuan yang cacat. ${ }^{21}$

\section{Pemahaman adalah Penerapan}

Awalnya tradisi hermeneutik dibedakan menjadi problem atau seluk beluk pemahaman (understanding, substilitas intelegendi), dan problem penafsiran (interpretation, substilitas explicandi.) Baru kemudian dalam tradisi pietisme ditambah elemen ketiga yaitu 
problem penerapan (application, substilitas applicandi.) ${ }^{1}$ Dengan menekankan elemen ketiga itu, yang belum masuk dalam konsep hermeneutik Schleiermacher maupun Dilthey, Gadamer mau menekankan bahwa penafsiran bukan suatu elemen tambahan yang bisa kadang-kadang saja dilakukan setelah pemahaman dilakukan. Namun dalam proses pengertian yang utuh selalu terkandung unsur pemahaman, penafsiran, dan penerapan. Sehingga tidak mengherankan jika Gadamer seringkali menyatakan ketiga elemen itu secara berurutan dalam proses mencapai suatu pengertian.

Melalui langkah pemahaman (understanding) dan penafsiran (interpretation) kita diajak masuk ke dalam elemen ketiga yaitu penerapan (application.) Melihat ketiga elemen itu sekaligus dalam satu kesatuan proses merupakan langkah lebih maju daripada dalam Hermeneutik Romantik. Sebagaimana telah dijelaskan sebelumnya, tindakan untuk mengerti suatu teks selalu mengandung suatu penerapannya dalam kaitannya dengan situasi orang yang ingin mengertinya. Dengan kata lain, melalui elemen penerapan ini kita diajak melihat bahwa pengertian beraspek kontekstual.

Gadamer meluaskan tugas hermeneutik tidak hanya sekedar mengangkat makna suatu teks dan mengungkapkannya dalam situasi penafsir seperti seorang penafsir orakel. Perluasan itu dilakukan karena bagi Gadamer, tugas hermeneutik bukan hanya sekedar mereproduksi apa yang pernah dikatakan seorang pengarang, namun makna itu harus diekspresikan dengan memertimbangkan penerapan dalam konteks jamannya.

Gadamer memberikan contoh untuk memerjelas konsep penerapan ini dalam hermeneutik hukum dan hermeneutik teologis karena kedua bentuk hermeneutik tersebut dapat menjadi model interpretasi literer. Kedua bentuk hermeneutik tersebut tidak hanya merupakan usaha untuk masuk ke suatu dunia masa lampau yang asing, tetapi juga usaha untuk menjembatani jarak temporal yang membentang antara teks masa lampau dengan situasi penafsir di jaman ini. Interpretasi yang terjadi adalah mengerti makna asali di dunia masa lampau itu sendiri dan apa artinya berkenaan dengan jaman kita sekarang. Dengan kata lain, mengerti sebuah teks secara lebih penuh terjadi dalam proses penerapan pada situasi konkrit. ${ }^{23}$ 
Dengan contoh di atas berarti bahwa pemahaman kita sekarang atas teks masa lampau mungkin sesuai dengan maksud pengarang teks yang bersangkutan atau mungkin juga tidak. Bahkan terbuka kemungkinan bahwa pemahaman yang terjadi di kemudian hari lebih memadai dan lebih luas daripada makna yang disadari pengarang waktu itu. Hal itu dimungkinkan, menurut Gadamer, karena kita tidak berusaha untuk bertemu dengan pengarang yang ada di balik teks itu tetapi kita berhadapan dengan teks itu sendiri. ${ }^{24}$

Seorang ahli hukum, misalnya, tidak hanya dituntut untuk mengerti kitab hukum dan undang-undang secara historis-harfiah karena ia masih harus membuat keputusan yang sah ketika berhadapan dengan kasus-kasus konkrit. Untuk sampai pada suatu keputusan konkrit mau tidak mau ia harus melakukan suatu interpretasi atas hal-hal umum yang termuat dalam kitab hukum yang berlaku di wilayahnya. Dalam melakukan hal itu, ia tidak dapat hanya sekedar didorong oleh kesewenang-wenangan. Dengan kata lain, ia harus menghindari apa yang dalam dunia hukum dikenal dengan istilah epikea (equity) yang berarti hak menurut keadilan atau kewajaran.

Ketika melakukan persidangan, seorang hakim dituntut mampu menerjemahkan hukum yang masih bersifat umum ke dalam kasuskasus konkrit dengan pedoman utama pada epikea atau hak atas keadilan dan kewajaran sang terdakwa. Berdasarkan prinsip itu baru dalam penerapan itulah hakim makin melihat dan mengerti maknanya, terutama kalau yang dihadapi adalah kasus-kasus yang belum pernah terjadi, yang mungkin belum diperhitungkan ketika kitab hukum itu disusun.

Dari contoh di atas dapat disimpulkan bahwa penafsiran tidak hanya merupakan tindak reproduksi makna-makna belaka namun juga merupakan tindak produksi. Dalam penafsiran terbukalah kemungkinan adanya perluasan makna. Gadamer menyatakan bahwa bisa saja terjadi makna suatu teks melampaui apa yang dimaksudkan oleh pengarang. ${ }^{25}$

\section{Pemahaman sebagai Proses Dialog}

Gadamer melanjutkan analisis mengenai pemahaman sebagai proses dialogis antara teks dan penafsir. Untuk memahami 
maksud Gadamer kita dapat melihat pada pemikiran hermeneutik Schleiermacher. Ia menyatakan bahwa hermeneutik adalah usaha untuk mengatasi keasingan antara pengarang dan penafsir yang dilakukan dengan melangsungkan sebuah pembicaraan. Usaha pemahaman itu menyangkut baik teks sebagai pokok persoalan (subject matter) maupun pikiran-pikiran penafsir. ${ }^{26}$

Gadamer mengandaikan teks masa lampau yang ingin dipahami sebagai Engkau (Thou) dan penafsir bertindak sebagai Aku (I) yang berada di masa kini yang melangsungkan pembicaraan. Dalam hubungan semacam itulah terbentuk pengalaman hermeneutik. Pengalaman ini memunyai ciri khas yang diistilahkan dengan keterbukaan kepada tradisi yang dipengaruhi oleh kesadaran sejarahefektif. Gadamer kemudian sampai pada kesimpulan penting dalam menganalisis struktur logis dari keterbukaan itu yang ditemukan dalam hubungan dialektis pertanyaan dan jawaban di mana bahasa menjadi mediumnya. Dalam hal ini Susan J. Hekman menjelaskan pemikiran Gadamer yang dapat dibagi dalam empat tahap berturutturut yaitu, pemikiran tentang hakekat pengalaman hermeneutik, keterbukaan sebagai inti pengalaman hermeneutik, analisis struktur logis keterbukaan yaitu hubungan antara pertanyaan dan jawaban, dan terakhir, pertimbangan mengenai hubungan antara pertanyaan dan jawaban yaitu aspek pembicaraan. ${ }^{27}$

\section{Hakekat Pengalaman Hermeneutik}

Gadamer mengawali penjelasan tentang pengalaman hermeneutik dengan mengritik konsep-konsep pengalaman yang berlaku umum yang menurutnya cenderung pada pembentukan pengetahuan tetapi mengesampingkan aspek-aspek kedalaman historisitas pengalaman. Hal itu terjadi karena ilmu pengetahuan terlalu didominasi oleh obsesinya untuk mengobyektifasi pengalaman. ${ }^{28}$ Metode ilmu-ilmu alam mendominasi cara kerja ilmu-ilmu kemanusiaan yang pada gilirannya menghapuskan aspek keberakaran pada historisitas yang merupakan esensi dari setiap pengalaman. Hal itu terjadi sebagai akibat logis dari cara kerja ilmu-ilmu positif yang menekankan pentingnya susunan metodis yang ketat dalam setiap eksperimennya.

Melawan pendapat yang menyatakan bahwa tindakan 
mengetahui yang sah hanyalah pengetahuan perseptual belaka dan yang dapat diverifikasi, Gadamer menyatakan bahwa pengalaman itu adalah sebuah peristiwa (event, happening) yang sarat dengan segi-segi manusiawi. Itulah sebabnya Gadamer berpaling kepada upaya Hegel dalam memberi makna kebenaran historis dialektikanya.

Bagi Hegel, pengalaman adalah produk dari perjumpaan dengan suatu obyek tertentu. Dengan demikian, pengalaman selalu memunyai struktur timbal balik, semacam gerak dialektis antara pengalaman yang sudah terakumulasi dalam diri seseorang dengan pengalaman baru. Gadamer mengutip apa yang ditulis oleh Hegel dalam bab terkhir Phenomenology of Mind sebagai berikut:

The dialectical movement that consciousness carries out in regard to itself, both in regard to its knowledge and to its object, inasmuch as its new true object emerges from this, is actually what is called 'experience. ${ }^{29}$

Hegel berpendapat bahwa pengalaman selalu memunyai struktur timbal balik atau rekonstruksi atas kesadaran yang berjalan dalam gerak dialektis. Unsur dialektiknya terletak pada kenyataan bahwa pengalaman baru yang masuk ke dalam kesadaran seseorang mampu mengubah pengetahuan dan pandangan seseorang atas pengalaman masa lalunya. Melanjutkan pemikiran di atas, Gadamer menyatakan bahwa pengalaman pertama-tama diperoleh melalui proses menegasi pengalaman baru yang dialami sebagai sesuatu yang asing.

Menurut Gadamer, pengalaman selalu dicapai melalui proses negatif, pengalaman baru merupakan suatu not-ness atau jalan negatif (via negativa. $)^{30}$ Istilah negatif di sini dimaksudkan bahwa pengalaman baru itu menjadikan orang memiliki perspektif baru dalam menyikapi pengalaman masa lalunya. Dengan demikian, pengalaman itu melekat pada hakekat historis manusia yang memberi kesan sebagai pertumbuhan yang menyakitkan. Tetapi dengan cara itulah pengalaman dicapai.

Palmer menilai bahwa Gadamer menyatakan unsur negatif dan kekecewaan merupakan bagian dari pengalaman karena menjadi bagian dari hakekat historis eksistensi manusia. ${ }^{31}$ Untuk memerjelas maksud hakekat pengalaman itu kita dapat melihat apa yang dikatakan Gadamer tentang Aeschylus, seorang dramawan besar dalam dunia kesusasteraan Yunani Kuno. ${ }^{32}$ Aeschylus mengemukakan ungkapan 
pathei mathos (belajar melalui penderitaan), secara sederhana dapat diartikan bahwa orang yang mengalami penderitaan atau tragedi yang merupakan pengalaman yang tidak enak, bahkan menyakitkan, dapat sampai pada kesadaran akan keterbatasannya sebagai manusia. Kemudian memunculkan pertanyaan, apakah makna semua itu? Bahkan tidak jarang pula dalam keadaan semacam itu kemudian kesadarannya juga terarah kepada Yang Ilahi atau menjadi suatu sikap yang memberontak kepada-Nya.

\section{Tiga Pola Hubungan I-Thou dan Keterbukaan}

Pengalaman hermeneutik berkenaan dengan apa yang telah diwariskan di dalam tradisi. Untuk mengerti tradisi, Gadamer mengambil tipologi hubungan Aku dan Engkau (I-Thou) sebagai analogi hubungan antara tradisi yang berupa teks dengan penafsirnya. Gadamer sejak awal sudah menegaskan agar teks tidak dipandang sebagai ungkapan kehidupan melainkan sebagai muatan maknamakna yang tidak terlepas dari ikatan-ikatan makna individual yang harus dibiarkan dirinya berbicara.

Relasi itu merupakan hubungan antar pribadi yang terjadi dalam sebuah percakapan sehingga memunyai bobot moral. Gadamer membedakannya ke dalam tiga macam pola hubungan dengan tujuan untuk menjelaskan hakekat kesadaran sejarah-efektif. Tiga macam pola hubungan itu adalah, Thou sebagai obyek $I$, Thou sebagai refleksi I, dan Thou sebagai Thou yang ditandai keterbukaan.

\section{Struktur Pertanyaan dan Jawaban}

Dalam dialog hermeneutik, pokok persoalan penting yang digeluti bersama antara teks dan penafsir adalah warisan tradisi. Tugas hermeneutik adalah bagaimana menempatkan teks itu kembali sehingga mampu berbicara sesuatu kepada penafsir. Menurut Gadamer, hal itu berlangsung dalam gerak dialektis percakapan yang memiliki struktur pertanyaan dan jawaban.

Gadamer berpendapat bahwa struktur pertanyaan secara tersirat ada dalam setiap pengalaman. Kita tidak dapat memiliki pengalaman tanpa mengajukan pertanyaan-pertanyaan. ${ }^{33}$ Alasannya karena di dalam setiap pertanyaan dan dalam usahanya untuk memahami ada 
suatu keterbukaan. Oleh karena itu, mengajukan pertanyaan menjadi penting dalam usaha untuk mencapai pemahaman.

Saat teks historis menjadi obyek penafsiran, dalam benak penafsir muncul banyak pertanyaan. Untuk dapat mengerti dan menafsirkan teks mau tidak mau berusaha mengerti jawaban-jawabannya. Hal itu dilakukan dengan pertama-tama memahami cakrawala hermeneutiknya sehingga mengungkapkan makna-makna yang mengarahkan teks itu. Dengan demikian, penafsir harus menanyakan makna yang ada di balik teks yang tampak langsung secara implisit. Gadamer menulis:

To understand the text means to understand this question. To interpret a text, the first requirement is to understand the horizon of meaning or of questioning within which the direction of meaning of the text is determined.

Makna suatu teks relatif terhadap pertanyaan yang spontan muncul, sehingga perlu menguak di balik apa yang tertulis. Teks harus ditempatkan di dalam cakrawala pertanyaan atau apa yang oleh Collingwood diistilahkan dengan re-enactment yang terdiri dari struktur logis pertanyaan dan jawaban. Gadamer mengutip apa yang dikatakan oleh Collingwood:

We can understand a text only when we have understood the question to which it is an answer. But since this question can be derived solely from the text and accordingly the appropriateness of the reply is the methodological presupposition for the reconstruction of the question.

Menurut Gadamer, mengajukan pertanyaan merupakan seni tersendiri. Pertama, kita tahu bahwa suatu pertanyaan itu harus mengarah pada sesuatu yang sama sekali belum diketahui. Kalau kita sudah tahu jawabannya atau kita pikir kita sudah tahu, tentu kita tidak akan bertanya. Kedua, kita juga tahu bahwa suatu pertanyaan harus menjadi suatu pertanyaan yang terarah. Yang dimaksud di sini adalah suatu pertanyaan yang diajukan oleh seseorang yang sungguh-sungguh tidak mengerti topik tertentu yang dibicarakan dan membutuhkan suatu jawaban atau beberapa alternatif jawaban. Ketiga, pertanyaan tersebut juga harus benar, karena dengan pertanyaan yang tidak benar ia sudah terhambat oleh penyajian pernyataan-pernyataan yang tidak 
benar juga. Keempat, Gadamer membedakan antara pertanyaan yang tidak benar dari pertanyaan yang terdistorsi. Dalam suatu pertanyaan yang terdistorsi, arah pertanyaannya tertuju kepada keterbukaan, namun geraknya tidak mengarah ke jalur yang semestinya, artinya sudah keluar dari fokus pembicaraan. Kelima, pertanyaan juga harus memuat sekaligus pertimbangan-pertimbangan yang positif maupun negatif. Entah pertanyaan tersebut dapat dijawab atau tidak, pada akhirnya semua alasan pro dan kontra harus disajikan, agar dapat diuji mana alasan-alasan yang tahan uji. ${ }^{36}$

Berkaitan dengan ini, Gadamer menandaskan pula bahwa datangnya suatu pertanyaan itu seperti 'suatu ide yang tiba-tiba' atau sebagai inspirasi. Maka sekalipun bertanya itu merupakan teknik atau seni, pertanyaan itu 'datang' kepada kita', 'menghadirkan diri pada kita' lebih daripada kita sendiri yang memunculkannya. ${ }^{1}$ Dengan demikian, seni bertanya, inspirasi dan datangnya pertanyaan pada kita menjadi kombinasi yang terdapat dalam struktur pemahaman Gadamer mengenai pertanyaan dan jawaban. Ada kombinasi antara keaktifan dan kepasifan, antara unsur Subyektif dan unsur obyektif dalam suatu waktu ketika kita mengajukan suatu pertanyaan. Ada unsur dialog antara pertanyaan dan jawaban, antara percakapan dengan pemahaman. Ini semua terlebur dalam pengalaman historis kita dan membentuk horison-horison yang selalu bergerak.

\section{Simpulan}

Ada lima hal yang perlu diperhatikan jika ingin melihat dasar pemikiran hermeneutik Gadamer. Pertama, aspek kesejarahan pemahaman (historicity of understanding). Gadamer mendasarkan analisis aspek tersebut pada uraian Heidegger mengenai pra-struktur pemahaman (pre-structure of understanding) dan aspek kesejarahan intrinsik (intrinsic historicality) dari eksistensi manusia. Analisis mengenai pra-struktur pemahaman memunculkan dua pertanyaan mendasar. Pertama, menyangkut dasar validitas penafsiran berkenaan dengan hubungan Subyek dan obyek. Kedua, memunculkan juga pertanyaan validitas dari apa yang sering diistilahkan dengan interpretasi obyektif atau 'interpretasi tanpa prasangka.' Terhadap kedua pertanyaan mendasar tersebut, Gadamer menjawab bahwa 
interpretasi tidak pernah merupakan suatu pencapaian tanpa prasangka yang telah ada sebelumnya. Ini berarti bahwa pemahaman selalu dipengaruhi oleh prasangka-prasangka yang diwariskan dari masa lalu.

Kedua, pemikiraan Gadamer mengenai prasangka (prejudice.) Berkaitan dengan aspek kesejarahan pemahaman, Gadamer mengasumsikan bahwa semua bentuk pemahaman selalu diwarnai oleh prasangka. Prasangka dan tradisi yang dalam pemikiran Hermeneutik Romantik selalu mendapat arti kurang baik justru menjadi batu penjuru bangunan pemikiran hermeneutik falsafi Gadamer. Secara eksplisit ia menyatakan bahwa pemikiran yang menyatakan bahwa prasangka selalu dipandang sebagai hal negatif dalam pemahaman itu berawal dari cara berpikir jaman Pencerahan. Gadamer mengusulkan rehabilitasi mendasar konsep prasangka, otoritas, dan tradisi. Dengan demikian, setiap usaha untuk memahami dan menafsirkan tidak dapat melepaskan diri dari prasangka. Menghindari setiap prasangka berarti mematikan pemikiran itu sendiri.

Ketiga, konsep kesadaran sejarah-efektif (effective-historical consciousness) menjadi basis terjadi relasi teks dan penafsir dalam proses peleburan cakrawala. Menurut Gadamer, pemahaman dapat dilakukan justru karena obyek yang hendak dipahami dan Subyek pemaham bukanlah dua hal yang saling terasing. Kedua mereka adalah bagian dari suatu tradisi budaya dan sejarah yang terbentuk dalam kontinuitas yang oleh Gadamer disebut dengan sejarah-efektif. Keempat, setelah melalui langkah pemahaman dan penafsiran, Gadamer mengajak masuk ke dalam elemen ketiga yaitu penerapan (application). Untuk mengerti suatu teks selalu mengandung penerapannya dalam kaitannya dengan situasi orang yang ingin mengertinya. Dengan kata lain, melalui penerapan kita diajak melihat bahwa pengertian beraspek kontekstual.

Kelima, proses dialogis dalam struktur pertanyaan dan jawaban terjadi dalam usaha pemahaman melalui analogi percakapan (conversation.) Pemahaman selalu dilakukan dalam proses dialogis yang ditipologikan dengan percakapan antara penafsir sebagai Aku (I) dan teks sebagai Engkau (Thou) dalam struktur pertanyaan dan jawaban. Ada tiga pola hubungan I-Thou: Thou sebagai obyek $I$, Thou sebagai refleksi $I$, dan Thou sebagai Thou yang ditandai keterbukaan. 
Gadamer lebih menekankan pada pola yang ketiga. Karena proses percakapan terjadi dalam bahasa sebagai mediumnya, maka Gadamer memasukkan aspek kebahasaan dalam menganalisis hakekat pemahaman.

\section{Catatan Akhir}

${ }^{1}$ Gadamer, Philosophical Hermeneutics (London: University of California Press, 1976), 8-9.

2 L.D. Derksen, On Universal Hermeneutics: A Study in The Philosophy of HansGeorg Gadamer (Amsterdam: VU Boekhandel/Uitgeverij, 1983), 108-110.

3 Richard Palmer, Hermeneutics: Interpretation Theory in Schleiermacher, Dilthey, Heidegger, and Gadamer (Evanston: Northwestern University Press, 1969), 86.

${ }^{4}$ Richard Palmer, Hermeneutics, 177.

5 Gadamer, Truth and Method (London: Sheed and Warp, 1975), 259.

6 Joseph Bleicher, Contemporary Hermeneutics: Hermeneutics as Method, Philosophy, and Critique (London: Routledge \& Kegan Paul, 1980), 100.

7 Gadamer, Truth and Method, 261.

${ }_{8}^{8}$ Gadamer, Truth and Method, 259.

9 Gadamer, Truth and Method, 263.

${ }^{10}$ Gadamer, Truth and Method, 264

${ }^{11}$ Bleicher, Contemporary Hermeneutics, 102

${ }^{12}$ Gadamer, Philosophical Hermeneutics, xiv.

${ }^{13}$ Gadamer, Truth and Method, 239.

${ }^{14}$ Gadamer, Truth and Method, 266.

${ }^{15}$ Gadamer, Truth and Method, 249.

${ }^{16}$ Gadamer, Truth and Method, 238.

${ }^{17}$ Gadamer, Truth and Method, 237.

${ }^{18}$ Gadamer, Truth and Method, 269.

${ }^{19}$ Susan J. Hekman, Hermeneutics and Sociology of Knowledge (Oxford: Polity Press, 1986), 95-96.

${ }^{20}$ Vincent P. Branick, An Ontology of Understanding (Saint Louis: Marianist Communications Center, 1974), 86.

${ }^{21}$ Gadamer, Truth and Method, 268.

${ }^{22}$ Menurut Palmer, ketiga elemen tersebut bukanlah tiga tahap metode yang terpisah-pisah. Istilah substilitas di sini dimaksudkan sebagai kapasitas kehalusan pembedaan dalam proses pemenuhan pemahaman. Lihat Palmer, Hermeneutics: Interpretation Theory, 187.

${ }^{23}$ Palmer, Hermeneutics, 188.

${ }^{24}$ Ankersmit lebih tegas lagi dalam menggarisbawahi kemungkinan itu dengan mengatakan bahwa bagi Gadamer usaha menafsirkan bukanlah usaha untuk mencari maksud pengarang yang tersembunyi di belakang teks, melainkan mencari apa yang terjadi antara teks dan penafsir dalam hubungan dialog yang 
dianggap seperti pembicaraan dua pribadi. Lihat Ankersmit, Refleksi Tentang Sejarah: Pendapat-pendapat Modern Tentang Filsafat Sejarah (Jakarta: Gramedia, 1987), 188.

${ }^{25}$ Gadamer, Truth and Method, 264.

${ }^{26}$ Branick, An Ontology of Understanding, 80-81.

${ }^{27}$ Hekman, Hermeneutics and Sociology of Knowledge, 108-109.

${ }^{28}$ Gadamer, Truth and Method, 310-311.

${ }^{29}$ Gadamer, Truth and Method, 318.

${ }^{30}$ Branick, An Ontology of Understanding, 122.

${ }^{31}$ Palmer, Hermeneutics: Interpretation Theory, 196

${ }^{32}$ Gadamer, Truth and Method, 320.

${ }^{33}$ Gadamer, Truth and Method, 325.

${ }^{34}$ Palmer, Hermeneutics: Interpretation Theory, 200.

${ }^{35}$ Gadamer, Truth and Method, 333.

${ }^{36}$ Gadamer, Truth and Method, 330.

${ }^{37}$ Gadamer, Truth and Method, 329.

\section{Daftar Pustaka}

Ankersmit. Refleksi Tentang Sejarah: Pendapat-pendapat Modern Tentang Filsafat Sejarah. Jakarta: Gramedia, 1987.

Bleicher, Joseph. Contemporary Hermeneutics: Hermeneutics as Method, Philosophy, and Critique. London: Routledge \& Kegan Paul, 1980.

Branick, Vincent P. An Ontology of Understanding. Saint Louis: Marianist Communications Center, 1974.

Derksen, L.D. On Universal Hermeneutics: A Study in The Philosophy of Hans-Georg Gadamer. Amsterdam: VU Boekhandel/Uitgeverij, 1983.

Gadamer. Philosophical Hermeneutics. London: University of California Press, 1976.

Gadamer. Truth and Method. London: Sheed and Warp, 1975.

Hekman, Susan J. Hermeneutics and Sociology of Knowledge. Oxford: Polity Press, 1986.

Palmer, Richard. Hermeneutics: Interpretation Theory in Schleiermacher, Dilthey, Heidegger, and Gadamer. Evanston: Northwestern University Press, 1969. 